\title{
Evergreen species response to Mediterranean climate stress factors
}

\author{
Loretta Gratani, Rosangela \\ Catoni, Laura Varone
}

\begin{abstract}
Recent climatic projections predict a decline in rainfall mainly during the summer period and an increase in air temperature for the Mediterranean basin, resulting in extended periods of soil water deficit. Mediterranean evergreen species attain drought resistance through different traits or combination of traits. The main objective of this research is to analyze the response of the evergreen species co-occurring in the Mediterranean maquis to variations in water availability and air temperature during the year. The results show that leaf structural traits significantly affect physiological traits as confirmed by the Partial Least Squares Regression analysis (PLS). In particular, the considered species have a similar leaf respiration $\left(R_{\mathrm{L}}\right)$ trend during the year with the lowest rates in winter (mean $0.95 \pm 0.44 \mu \mathrm{mol} \mathrm{m}^{-2} \mathrm{~s}^{-1}$ ) and the highest in drought (mean $3.05 \pm 0.96 \mu \mathrm{mol} \mathrm{m} \mathrm{m}^{-2} \mathrm{~s}^{-1}$ ). Nevertheless, a different $R_{\mathrm{L}}$ effect on gross photosynthesis $\left(P_{\mathrm{G}}\right)$ during drought was observed. $C$. incanus, $E$. multiflora, $R$. officinalis and $S$. aspera have the highest $R_{\mathrm{L}} / P_{\mathrm{G}}$ ratio (mean $0.54 \pm 0.08$ ), while $Q$. ilex, $P$. latifolia, $P$. lentiscus, $A$. unedo and $E$. arborea have the lowest (mean $0.22 \pm 0.07) . R_{\mathrm{L}} / P_{\mathrm{G}}$ ratio variations depend on the sensitivity of both the two parameters to drought. Considering the increase of the length and intensity of drought in the Mediterranean basin, and that the photosynthesis of Mediterranean evergreen species is frequently limited by sub-optimal conditions (i.e., water deficit, high light intensity and high air temperature), it is important to improve knowledge on $R_{\mathrm{L}}$, since it has a critical function in modulating carbon balance of Mediterranean species.
\end{abstract}

Keywords: Global Climate Change, Mediterranean Evergreen Species, Net Photosynthesis, Gross Photosynthesis, Leaf Respiration fall mainly during summer (IPCC 2014). Moreover, the Mediterranean basin undergoes more prolonged dry periods than in the past. This produces a negative soil water balance as the amount of water that evaporates overcomes the amount of wasummer humidity (Brunetti et al. 2002, Moretti et al. 2015). The Mediterranean basin is characterized by a high plant diversity of growth forms, habits and phenology (Galmés et al. 2007). In particular, physiological adaptations involve regulation of the water status by stomatal control (Gratani \& Varone 2004). Morphological and anatomical adaptations involve leaf protective structures (i.e., hairs, thick cuticle, sclerenchymatic cells), steep leaf inclination, low leaf surface area (Castro-Díez et al. 1998, Karabourniotis 1998, Gratani \& Bomter intercepted by soil through rainfall and

Department of Environmental Biology, Sapienza University of Rome, P.le A. Moro 5, 00185 Rome (Italy)

@ Loretta Gratani (loretta.gratani@uniroma1.it)

Received: Sep 01, 2015 - Accepted: Apr 06, 2016

Citation: Gratani L, Catoni R, Varone L (2016). Evergreen species response to Mediterranean climate stress factors. iForest 9: 946-953. - doi: 10.3832/ifor1848-009 [online 2016-07-07]

Communicated by: Elena Paoletti belli 2000) and a high stomatal density of small size (Rotondi et al. 2003, Gratani \& Varone 2004). Such traits improve drought resistance by decreasing photochemical damage of the photosynthetic apparatus and limiting leaf transpiration (Castro-Díez et al. 1998). Among the Mediterranean species, the sclerophyllous have a high construction cost of their leaf protective structures (i.e., high leaf consistency) and a long leaf longevity (Gratani \& Crescente 1997), while the semi-deciduous species have a lower leaf consistency and a shorter leaf longevity. Moreover, they have leaf morphological and anatomical differences between summer and winter leaves (Catoni et al. 2012). Leaf longevity may be a source of variation in the relationship among the different leaf traits (Reich et al. 1991). Nevertheless, if the dry season lasts too long, water deficit may negatively affect Mediterranean evergreen species carbon assimilation, as a result of the lowest photosynthetic rates and leaf surface areas produced (Pereira et al. 2007). Thus, plant survival in Mediterranean environments depends largely upon their capacity to photosynthesize and keep water loses lower than the supply. It is important to take into account the key role of leaf respiration when plants experience intense drought periods, since it has a critical function in modulating carbon balance (Sun et al. 2014). The effects of leaf respiration on 
gross photosynthesis, particularly under drought conditions (Flexas et al. 2005) may allow more reliable climate change scenarios of ecosystem functioning.

In this context, the main goal of our research was to analyze the response of the evergreen species co-occurring in the Mediterranean maquis to seasonal variations in water availability and air temperature during the year. In particular, the effects of leaf respiration on gross photosynthesis were considered. The Mediterranean maquis is largely distributed in areas around the Mediterranean Basin and its structure and composition is strongly influenced by air temperature and water availability (Gratani et al. 2013).

\section{Material and methods}

\section{Study area and plant materials}

The study was carried out in the period January - December 2014 in the Mediterranean maquis inside the Presidential Estate of Castelporziano (SSW of Rome, Italy; $4^{\circ} 45^{\prime} \mathrm{N}, 12^{\circ} 26^{\prime} \mathrm{E}$ - http://palazzo.qui rinale.it/residenze/c_porziano_en.html).

The Presidential Estate of Castelporziano is included in the "Natura 2000" network and is classified as a ZPS (Special Protection Area, "Tenuta Presidenziale", IT603 0084) and a SIC (Sites of Community Importance) with two areas: "Querceti igrofili" (IT6030028) and "Fascia costiera" (IT6030027). The maquis under study was characterized by the presence of the following species: Arbutus unedo L., Phillyrea latifolia L., Pistacia lentiscus L., Quercus ilex L. (typical sclerophyllous species), Cistus incanus L. (drought semi-deciduous species), Erica arborea L., Erica multiflora L., Rosmarinus officinalis L. (narrow-leaves species), and Smilax aspera L. (liana - Gratani \& Crescente 1997).

The climate of the area is Mediterranean, with the mean minimum air temperature $\left(T_{\min }\right)$ of the coldest months (February) of $3.7 \pm 1.8{ }^{\circ} \mathrm{C}$ (mean $\left.\pm \mathrm{SD}\right)$, the mean maximum air temperature $\left(T_{\max }\right)$ of the hottest months (August) $30.3 \pm 1.4^{\circ} \mathrm{C}$, and the mean yearly air temperature $\left(T_{\mathrm{m}}\right) 15.6 \pm 5.9$ ${ }^{\circ} \mathrm{C}$. Total annual rainfall is $738 \mathrm{~mm}$, mainly occurring in autumn and winter. Drought period is from the end of May to the beginning of September (6o $\mathrm{mm}$ in the period). During the study period, $T_{\min }$ of the coldest month (March) was $5.0 \pm 2.1^{\circ} \mathrm{C}, \mathrm{T}_{\max }$ of the hottest month (August) $28.0 \pm 2.4^{\circ} \mathrm{C}$ and the total rainfall during the drought period (from the end of July to the end of August) was $15 \mathrm{~mm}$ (Fig. 1). Weather and climate data (1985-2014) were obtained from the Meteorological Station located inside the Estate.

Structural, morphological, anatomical and physiological leaf traits were measured on twelve representative shrubs per each of the considered species, randomly distributed in three representative areas (100 $\mathrm{m}^{2}$ each). Mature leaves were detached from the southern, upper portion of each shrub at the end of May 2014 for measurements.

\section{Structural shrubs traits}

Measurements of shrub structure included total height $\left(H_{\mathrm{s}}\right.$, defined as the maximum vertical distance from the ground to the highest point of the shrub), height of the shrub crown ( $\mathrm{Ch}$, defined as the vertical distance from the lowest leaf insertion to the highest point of the shrub), depth of the shrub crown $(C D$, excluding the central non-foliated branch portion, according to Schulze et al. 1977), major axis $(A)$ and minor axis ( $a$, orthogonal to $A$ ) of the shrub crown. Shrub volume $\left(V_{\mathrm{S}}\right)$ was derived from the measured traits, by assigning simple geometric solids to shrub form, such as cone, semisphere and ellipsoid

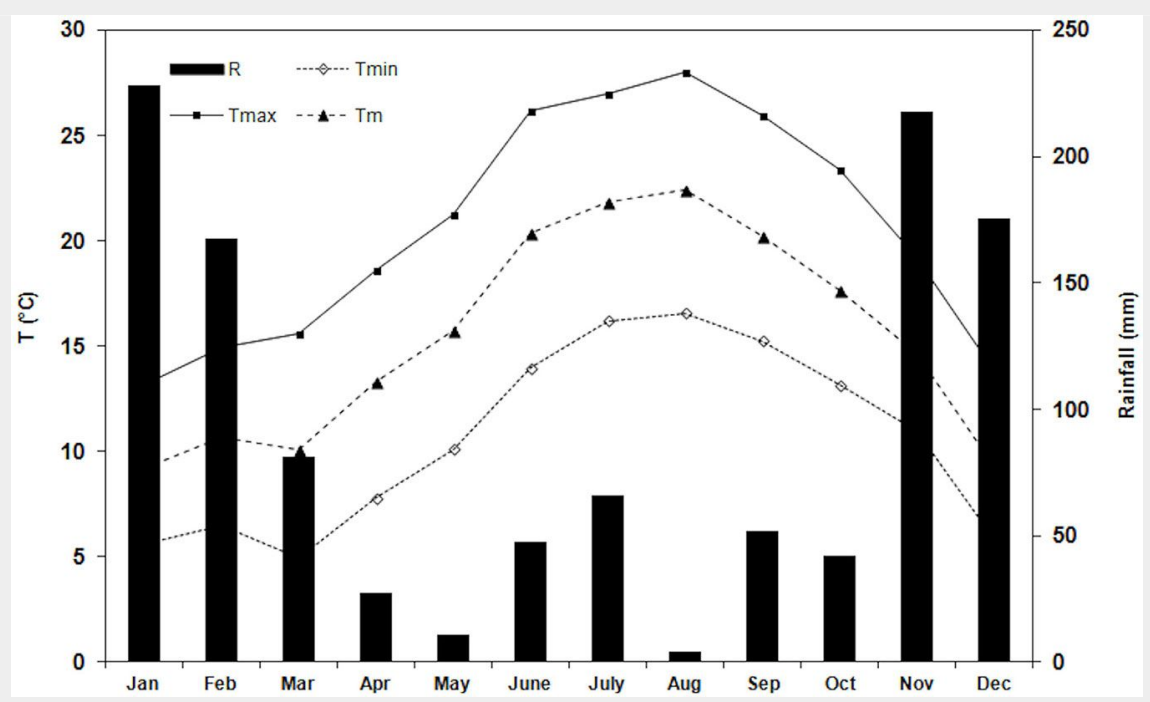

Fig. 1 - Monthly trend of air temperatures and total monthly rainfall during the study period (January - December 2014); (R): total monthly rainfall $\left(T_{\min }\right)$ : minimum air temperature; $\left(T_{\max }\right)$ : maximum air temperature; $\left(T_{m}\right)$ : mean air temperature. which appeared to give the best fit of the natural shape of the crown, according to Sternberg \& Shoshany (2001); the volume of the shrub crown $\left(V_{\text {crown }}\right)$ was calculated excluding the central non-foliated branch portion of shrub. For S. aspera was measured the length $\left(l_{s}\right)$.

\section{Anatomical leaf traits}

The following parameters were considered for leaf anatomical measurements ( $n$ $=3$ leaves per shrub per species): total leaf lamina thickness (LT); palisade and spongy thickness; thickness of the upper and lower cuticle and epidermis (CET, $\mu \mathrm{m})$. Measurements were restricted to vein-free areas. The fraction of mesophyll volume occupied by the intercellular air spaces ( $f_{\text {ias, }}$, $\%$ ) was calculated according to Syvertsen et al. (1995) as follows (eqn. 1):

$$
f_{\text {ias }}=1-A_{m} / l \mathrm{~W}
$$

where $A_{\mathrm{m}}$ is the cross-sectional area of the mesophyll cell, $W$ the width of the measured section and $l$ is the mesophyll thickness.

The following parameters were measured for stomata: guard cell length and width ( $L_{\mathrm{A}}$ and $W_{\mathrm{B}}$, respectively), according to Stojnić et al. (2015), and the stomatal pore surface of stomata guard cell $\left(S P S_{\perp A W B}, \mu m^{2}\right)$, according to Balasooriya et al. (2009) as (eqn. 2):

$$
S P S_{L A W B}=\left(L_{A} \cdot W_{B} \cdot \pi\right) / 4
$$

The potential conductance index $(P C I)$ was calculated according to Holland \& Richardson (2009), as follows (eqn. 3):

$$
P C I=L_{A}^{2} \cdot S D \cdot 10^{-4}
$$

where $S D$ is the stomatal density (stomata $\mathrm{mm}^{-2}$ ), measured from nail varnish impressions of the inferior lamina, according to Sack et al. (2003), each of them $0.5 \times 1.0$ $\mathrm{cm}$, obtained by a Zeiss Axiocam MRc $5^{\oplus}$ digital camera (Carl Zeiss, Jena, Germany), equipped with the software Axiovision $A C^{\circledR}$ (release 4.5).

\section{Morphological leaf traits}

The following parameters were measured for leaf morphological measurements $(n=$ 5 leaves per shrub per species): projected fresh leaf surface area excluding petioles $\left(L A, \mathrm{~cm}^{2}\right)$, obtained by the Image Analysis System ${ }^{\circledast}$ (Delta-T Devices, Burwell, UK) and leaf dry mass $(D M, \mathrm{mg})$, drying leaves at 80 ${ }^{\circ} \mathrm{C}$ to constant mass.

Leaf mass per unit leaf area ( $L M A, \mathrm{mg}$ $\mathrm{cm}^{-2}$ ) was calculated by the ratio of $D M$ and $L A$ and leaf tissue density ( $L T D, \mathrm{mg} \mathrm{cm}^{-3}$ ) by the ratio of $L M A$ and total lamina thickness.

\section{Gas exchange}

Gas exchange measurements were carried out using an infrared gas analyzer (LCPro+ ${ }^{\oplus}$, ADC Bioscientific Ltd., Hoddes- 
don, UK) equipped with a conifer leaf chamber (PLC, Parkinson Leaf Chamber) for E. arborea, E. multiflora and R. officinalis, and with a broad leaf chamber (PLC) for Q. ilex, A. unedo, C. incanus, P. latifolia, P. lentiscus and $S$. aspera. Measurements were taken on fully expanded sun leaves ( $\mathrm{n}$ $=6$ per each sampling occasion for $A$. unedo, C. incanus, P. latifolia, P. lentiscus, Q. ilex, and S. aspera) and on sun apical shoots ( $\mathrm{n}=6$ per each sampling occasion for E. arborea, E. multiflora and R. officinalis). Net photosynthetic rate $\left(P_{\mathrm{N}}, \mu \mathrm{mol}\right.$ $\left.\mathrm{CO}_{2} \mathrm{~m}^{-2} \mathrm{~s}^{-1}\right)$, stomatal conductance $\left(g_{\mathrm{s}}\right.$, mol $\left.\mathrm{H}_{2} \mathrm{O} \mathrm{m}^{-2} \mathrm{~s}^{-1}\right)$, leaf transpiration $\left(E, \mathrm{mmol} \mathrm{H}_{2} \mathrm{O}\right.$ $\left.\mathrm{m}^{-2} \mathrm{~s}^{-1}\right)$, sub-stomatal $\mathrm{CO}_{2}$ concentration $\left(C_{\mathrm{i}}\right.$, $\mu \mathrm{mol} \mathrm{CO} \mathrm{mol}^{-1}$ air), leaf temperature $\left(T_{1},{ }^{\circ} \mathrm{C}\right)$ and photosynthetic photon flux density (PPFD, $\mu \mathrm{mol}$ photons $\mathrm{m}^{-2} \mathrm{~s}^{-1}$ ) were measured from 9.00 to 11.00 a.m., under natural conditions, on cloud-free days ( $P P F D>$ $1000 \mu \mathrm{mol} \mathrm{m} \mathrm{m}^{-2} \mathrm{~s}^{-1}$, saturating level) to ensure that the near maximum daily photosynthetic rates were measured (Reich et al. 1999). The apparent carboxylation efficiency of Rubisco $\left(P_{\mathrm{N}} / C_{\mathrm{i}}\right.$, mol $\left.\mathrm{CO}_{2} \mathrm{~m}^{-2} \mathrm{~s}^{-1}\right)$ was determined according to Arena et al. (2013).

Leaf dark respiration rate $\left(R_{\mathrm{L}}, \mu \mathrm{mol} \mathrm{CO}_{2}\right.$ $\left.\mathrm{m}^{-2} \mathrm{~s}^{-1}\right)$ measurements were carried out contemporary to photosynthesis measurements, by darkening the leaf chamber with a black paper for 30 min prior to each measurement to avoid transient post-illumination bursts of $\mathrm{CO}_{2}$ releasing. Measurements were carried out in four sampling days with the same weather conditions for each month.

Gross photosynthetic rates $\left(P_{\mathrm{C}}, \mu \mathrm{mol} \mathrm{CO}_{2}\right.$ $\mathrm{m}^{-2} \mathrm{~s}^{-1}$ ) were calculated as the sum of the average values for $P_{\mathrm{N}}$, photorespiration and $R_{\mathrm{L}}$, based on the assumption that $R_{\mathrm{L}}$ (excluding photorespiration) were similar in the light and in the dark (Van lersel 2003). Photorespiration rates $\left(P_{\mathrm{r}}, \mu \mathrm{mol} \mathrm{CO}\right.$ $\mathrm{m}^{-2} \mathrm{~s}^{-1}$ ) were evaluated considering that under natural conditions C3 plants lose about $20 \%$ of the photosynthetically acquired $\mathrm{CO}_{2}$ in the form of photorespiratory $\mathrm{CO}_{2}$ (Larcher 2003). Total yearly $P_{\mathrm{N}}$ and $R_{\mathrm{L}}$ ( $P_{\mathrm{Ny}}$ and $R_{\mathrm{Ly}}$, respectively) were calculated on the basis of the daily photosynthetic and respiratory activity, according to Van lersel (2003), extending data over the whole year. The ratio $R_{\mathrm{L}} / P_{\mathrm{C}}$ was calculated according to Chastain et al. (2014). Total yearly $P_{\mathrm{C}}\left(P_{\mathrm{Cy}}\right)$ and the fraction of total yearly $R_{\mathrm{Ly}}$ on $P_{\mathrm{cy}}\left(R_{\mathrm{Ly}} / P_{\mathrm{Cy}}\right)$ were also calculated.

\section{Leaf water status}

Leaf water potential at pre-dawn $\left(\Psi_{\mathrm{pd}}\right)$ was measured on leaves of $A$. unedo, $C$. incanus, P. latifolia, P. lentiscus, Q. ilex, and S. aspera and on shoots of E. arborea, E. multiflora, R. officinalis (five leaves and five apical shoots per species, respectively, per each sampling occasion). $\Psi$ measurements were carried out using a portable pressure chamber (SKPM $1400^{\circledR}$, Skye Instruments, Llandrindod Wells, Powys, UK). Relative
Tab. 1 - Mean values and standard deviation of shrub height $\left(H_{\mathrm{s}}, \mathrm{m}\right)$, shrub volume $\left(V_{\mathrm{s}}\right.$, $\left.\mathrm{m}^{3}\right)$ and volume of shrub crown $\left(V_{\text {crown }}, \mathrm{m}^{3}\right)$ in the considered species $(\mathrm{n}=12)$.

\begin{tabular}{lccc}
\hline Species & $\boldsymbol{H}_{\mathrm{s}}(\mathrm{m})$ & $\boldsymbol{V}_{\mathrm{s}}\left(\mathrm{m}^{3}\right)$ & $\boldsymbol{V}_{\text {crown }}\left(\mathrm{m}^{3}\right)$ \\
\hline A.unedo & $1.01 \pm 0.22$ & $1.58 \pm 1.41$ & $0.59 \pm 0.43$ \\
C.incanus & $0.76 \pm 0.11$ & $0.32 \pm 0.24$ & $0.20 \pm 0.12$ \\
E. arborea & $1.72 \pm 0.24$ & $3.55 \pm 1.27$ & $1.74 \pm 0.75$ \\
E. multiflora & $0.85 \pm 0.23$ & $1.24 \pm 0.75$ & $0.38 \pm 0.23$ \\
P.latifolia & $1.32 \pm 0.31$ & $1.77 \pm 0.84$ & $0.48 \pm 0.25$ \\
P.lentiscus & $0.90 \pm 0.13$ & $0.60 \pm 0.46$ & $0.22 \pm 0.10$ \\
Q.ilex & $1.45 \pm 0.32$ & $7.16 \pm 5.20$ & $2.72 \pm 1.24$ \\
R.officinalis & $0.87 \pm 0.18$ & $1.48 \pm 1.35$ & $0.85 \pm 0.55$ \\
S.aspera & $1.50 \pm 0.40$ & - & - \\
\hline
\end{tabular}

water content at pre-dawn $\left(R W C_{\mathrm{pd}}\right)$ was calculated at the same time and on the same leaves used for $\Psi$ measurements as (eqn. 4):

$$
R W C=\frac{F M-D M}{T M-D M} \cdot 100
$$

\section{Results}

\section{Structural shrub traits}

Structural shrub traits of the considered species are shown in Tab. 1. In particular, among the species analyzed, E. arborea showed the highest $H_{\mathrm{S}}(1.72 \pm 0.24 \mathrm{~m})$ and where $F M$ is the leaf fresh mass, $D M$ the leaf mass after drying at $90{ }^{\circ} \mathrm{C}$ until constant mass was reached, and $T M$ the leaf mass after rehydration until saturation for $48 \mathrm{~h}$ at $5^{\circ} \mathrm{C}$ in the darkness (Bacelar et al. 2007). $\Psi_{\mathrm{pd}}$ and $R W C_{\mathrm{pd}}$ measurements were carried out in April and May (during the favorable period) and in August (during drought), simultaneously with gas exchange measurements.

\section{Statistical analysis}

All statistical tests were performed using the software package Statistica ${ }^{\circledast}$ v. 10.0 (Statsoft Inc., Tulsa, OK, USA).

The differences in physiological leaf traits were determined by the analysis of variance (ANOVA) and the post-hoc Tukey's test for multiple comparisons ( $\alpha \leq 0.05)$. Data were tested for normality and homogeneity of variances before carrying out the statistical analysis, with $\alpha \leq 0.05$.

A Partial Least Squares Regression analysis (PLS) was carried out to explore the pattern of co-variation between morphological and physiological leaf traits and to establish the order of the variable importance (i.e. VIP). PLS was carried out using the structural leaf traits ( $L M A, L T D, L T$, $C E T, P C I$ and $\left.f_{\text {ias }}\right)$ as predictor variables and physiological traits $\left(P_{\mathrm{N}}, R_{\mathrm{L}}, R_{\mathrm{L}} / P_{\mathrm{G}}, \Psi\right.$ and $R W C)$ as the response variables.

C. incanus the lowest $(0.76 \pm 0.11 \mathrm{~m})$. Q. ilex was the species with the highest $V_{\mathrm{s}}$ and $V_{\text {crown }}$ values $\left(7.16 \pm 5.20 \mathrm{~m}^{3}\right.$ and $2.72 \pm 1.24$ $\mathrm{m}^{3}$, respectively), while $C$. incanus the lowest ones $\left(0.32 \pm 0.24 \mathrm{~m}^{3}\right.$ and $0.20 \pm 0.12 \mathrm{~m}^{3}$, respectively).

\section{Anatomical and morphological leaf traits}

E. arborea showed the lowest $L T(200 \pm$ $19 \mu \mathrm{m})$, followed by $C$. incanus $(217 \pm 9 \mu \mathrm{m})$, P. lentiscus (254 $\pm 18 \mu \mathrm{m}), A$. unedo (300 \pm $20 \mu \mathrm{m})$, Q. ilex, P. latifolia and S. aspera ( 316 $\pm 5 \mu \mathrm{m}$, mean value) and by $R$. officinalis and E. multiflora ( $335 \pm 7 \mu \mathrm{m})$.

$C E T$ was the highest in P. latifolia $(43 \pm 3$ $\mu \mathrm{m})$, followed by E. multiflora $(41 \pm 2 \mu \mathrm{m})$, A. unedo $(35 \pm 4 \mu \mathrm{m}), E$. arborea and $R$. officinalis ( $26 \pm 3 \mu \mathrm{m}$, mean value), $\mathrm{S}$. aspera $(25 \pm 2 \mu \mathrm{m})$, Q. ilex ( $22 \pm 1 \mu \mathrm{m}), P$. lentiscus $(16 \pm 2 \mu \mathrm{m})$ and $C$. incanus $(14 \pm 2$ $\mu \mathrm{m})$.

A. unedo and $C$. incanus showed the highest $f_{\text {ias }}(37 \pm 1 \%$, mean value), followed by P.lentiscus, Q. ilex and P. latifolia ( $31 \pm 3 \%$, mean value), $R$. officinalis, E. multiflora and E. arborea ( $26 \pm 1 \%$, mean value) and $S$. aspera $(15 \pm 3 \%)$.

$S P S_{\text {LAWB }}$ and $P C I$ varied significantly among the considered species (Tab. 2), P. latifolia having the highest $S P S_{\text {LAWB }}(574 \pm$ $\left.96 \mu \mathrm{m}^{2}\right)$ and E. arborea the lowest one (155

Tab. 2 - Mean values and standard deviation of stomatal pore surface of stomata guard cell $\left(S P S_{\mathrm{LAWB}}, \mu \mathrm{m}^{2}\right)$ and potential conductance index $(P C I)$ in the considered species $(n=36)$. Mean values with the same letters are not significantly different after Tukey's test $(P \geq 0.05)$.

\begin{tabular}{lcr}
\hline Species & $\boldsymbol{S P S}_{\text {LAWB }}\left(\mu \mathrm{m}^{2}\right)$ & $\boldsymbol{P C I}$ \\
\hline A.unedo & $428 \pm 50^{\mathrm{a}}$ & $18.2 \pm 2.8^{\mathrm{a}}$ \\
C.incanus & $207 \pm 47^{\mathrm{c}}$ & $7.8 \pm 2.0^{\mathrm{d}}$ \\
E. arborea & $155 \pm 21^{\mathrm{c}}$ & $6.0 \pm 0.8^{\mathrm{d}}$ \\
E. multiflora & $238 \pm 20^{\mathrm{c}}$ & $6.5 \pm 0.7^{\mathrm{d}}$ \\
P.latifolia & $574 \pm 96^{\mathrm{b}}$ & $23.5 \pm 4.0^{\mathrm{b}}$ \\
P.lentiscus & $242 \pm 25^{\mathrm{c}}$ & $15.4 \pm 1.6^{\mathrm{a}}$ \\
Q.ilex & $389 \pm 56^{\mathrm{a}}$ & $31.2 \pm 3.0^{\mathrm{c}}$ \\
R.officinalis & $219 \pm 47^{\mathrm{c}}$ & $5.5 \pm 1.4^{\mathrm{d}}$ \\
S.aspera & $400 \pm 45^{\mathrm{a}}$ & $9.2 \pm 1.4^{\mathrm{d}}$ \\
\hline
\end{tabular}


Tab. 3 - Mean values and standard deviations of leaf mass per area $\left(L M A, \mathrm{mg} \mathrm{cm}^{-2}\right)$ and leaf tissue density $\left(L T D, \mathrm{mg} \mathrm{cm}^{-3}\right)$ in the considered species $(\mathrm{n}=60)$. Mean values with the same letters are not significantly different after Tukey's test $(P \geq 0.05)$.

\begin{tabular}{lcc}
\hline Species & $\boldsymbol{L M A}\left(\mathbf{m g ~ c m}^{-2}\right)$ & $\boldsymbol{L T D}\left(\mathbf{m g ~ c m}^{-3}\right)$ \\
\hline A. unedo & $15.8 \pm 0.6^{\mathrm{c}}$ & $419 \pm 20^{\mathrm{b}}$ \\
C. incanus & $15.1 \pm 0.7^{\mathrm{bc}}$ & $580 \pm 16^{\mathrm{e}}$ \\
E. arborea & $12.0 \pm 1.1^{\mathrm{a}}$ & $510 \pm 12^{\mathrm{c}}$ \\
E. multiflora & $26.3 \pm 1.7^{\mathrm{f}}$ & $760 \pm 23^{\mathrm{f}}$ \\
P. latifolia & $20.1 \pm 1.2^{\mathrm{de}}$ & $515 \pm 18^{\mathrm{c}}$ \\
P. lentiscus & $18.9 \pm 1.0^{\mathrm{de}}$ & $548 \pm 25^{\mathrm{d}}$ \\
Q. ilex & $20.4 \pm 1.1^{\mathrm{e}}$ & $622 \pm 16^{\mathrm{f}}$ \\
R. officinalis & $20.8 \pm 0.6^{\mathrm{de}}$ & $580 \pm 15^{\mathrm{e}}$ \\
S. aspera & $13.9 \pm 0.8^{\mathrm{b}}$ & $355 \pm 32^{\mathrm{a}}$ \\
\hline
\end{tabular}

$\left.\pm 21 \mu \mathrm{m}^{2}\right)$. Q. ilex had the highest $P C I(31.2 \pm 3)$. In particular, $L M A$ value ranged from 3.0) while R. officinalis, E. multiflora and $E . \quad 26.3 \pm 1.7 \mathrm{mg} \mathrm{cm}^{-2}$ (E. multiflora) to $12.0 \pm 1.1$ arborea the lowest $\left(6.0 \pm 0.5\right.$, mean value). $\quad \mathrm{mg} \mathrm{cm}^{-2}$ (E. arborea) and LTD from $760 \pm 23$

Morphological leaf traits varied signifi- $\mathrm{mg} \mathrm{cm}^{-3}$ (E. multiflora) to $355 \pm 32 \mathrm{mg} \mathrm{cm}^{-3}$ cantly among the considered species (Tab. (S. aspera).
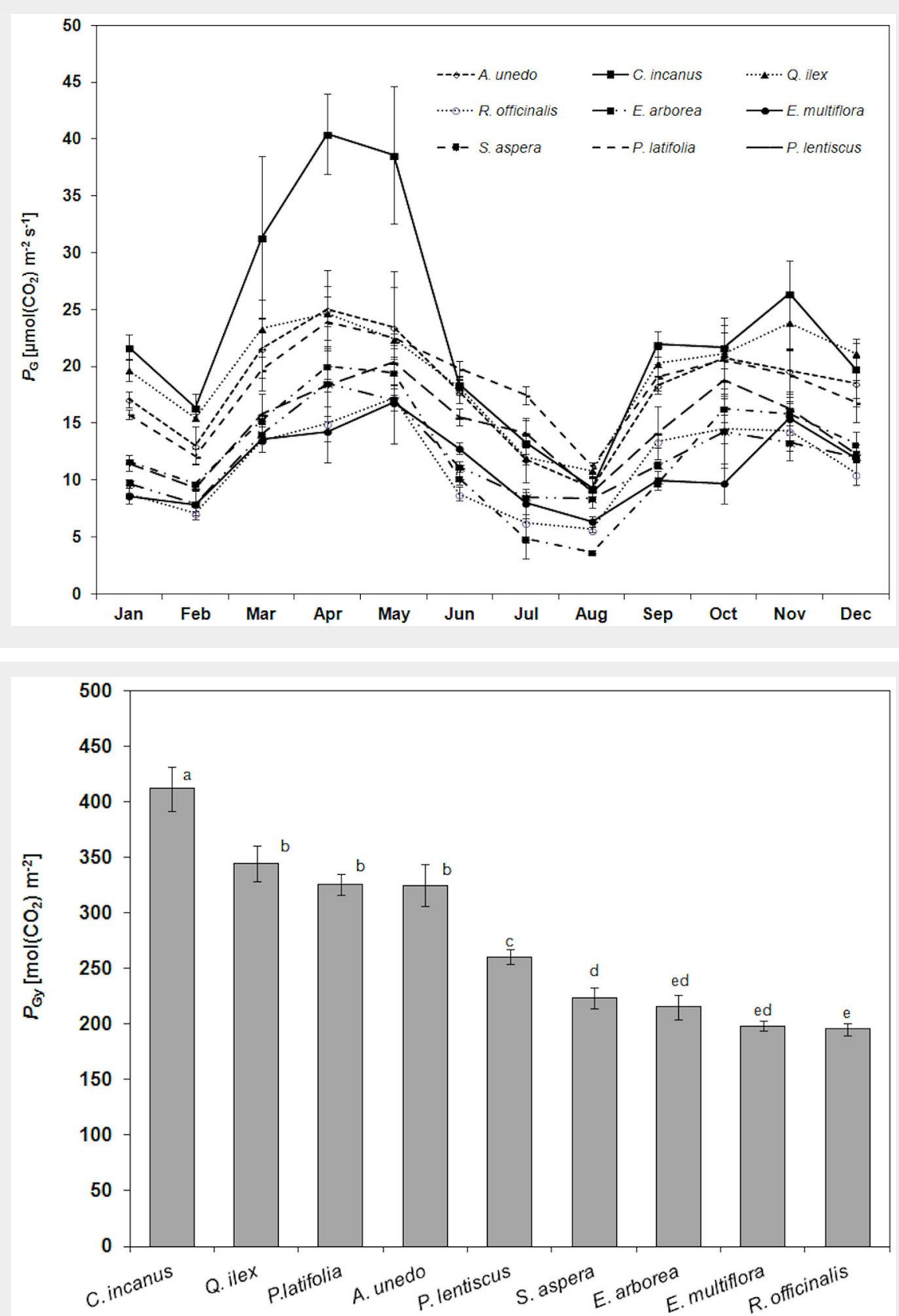

\section{Gas exchange}

The considered species had the same $R_{\mathrm{L}}$ trend during the year. The lowest rates were measured in winter (January-February: $0.95 \pm 0.44 \mu \mathrm{mol} \mathrm{m} \mathrm{m}^{-2} \mathrm{~s}^{-1}$, mean value) and the highest in August (3.05 \pm 0.96 $\mu \mathrm{mol} \mathrm{m}^{-2} \mathrm{~s}^{-1}$, mean value). In particular, $R$. officinalis had the highest $R_{\mathrm{L}}$ in August (4.5 $\left.\pm 1.6 \mu \mathrm{mol} \mathrm{m}^{-2} \mathrm{~s}^{-1}\right)$ and P. latifolia the lowest $\left(1.58 \pm 0.05 \mu \mathrm{mol} \mathrm{m} \mathrm{m}^{-2} \mathrm{~s}^{-1}\right)$.

The species analyzed shared the same $P_{c}$ trend during the year (Fig. 2), though some differences were observed. A relatively low $P_{G}$ value $\left(12.4 \pm 4.3 \mu \mathrm{mol} \mathrm{m}^{-2} \mathrm{~s}^{-1}\right.$, mean value) was monitored in winter (January-February), $R$. officinalis having the lowest rate $\left(7.9 \pm 1.2 \mu \mathrm{mol} \mathrm{m} \mathrm{m}^{-2} \mathrm{~s}^{-1}\right)$ and $C$. incanus the highest $\left(19.0 \pm 3.7 \mu \mathrm{mol} \mathrm{m}^{-2} \mathrm{~s}^{-1}\right)$. The highest $P_{\mathrm{G}}\left(22.0 \pm 7.1 \mu \mathrm{mol} \mathrm{m} \mathrm{m}^{-2} \mathrm{~s}^{-1}\right.$, mean value) was measured in April-May, $C$. incanus having the highest $P_{\mathrm{G}}\left(39.5 \pm 1.3 \mu \mathrm{mol} \mathrm{m} \mathrm{m}^{-2}\right)$, fol-
Fig. 2 - Trend of leaf gross photosynthesis $\left(P_{\mathrm{G}}, \mu \mathrm{mol} \mathrm{CO} \mathrm{Cm}^{-2} \mathrm{~s}^{-1}\right)$ during the study period for the considered species. Each point is the mean value of four sampling days per months $(n=24)$. Mean values (points) and standard deviation (error bars) are shown.
Fig. 3 - Mean values and standard deviation (error bars) of yearly gross photosynthesis $\left(P_{\mathrm{Gy}}, \mathrm{mol} \mathrm{CO}_{2} \mathrm{~m}^{-2}\right)$ in the considered species $(n=12)$. Mean values with the same letters are not significantly different after Tukey's test $(P \geq 0.05)$. 
Fig. 4 - Trend of the ratio of leaf respiration to gross photosynthesis $\left(R_{\llcorner} / P_{\mathrm{G}}\right)$ during the study period. Each point is the mean value of four sampling days per months $(n=24)$. Error bars represent the standard deviation.

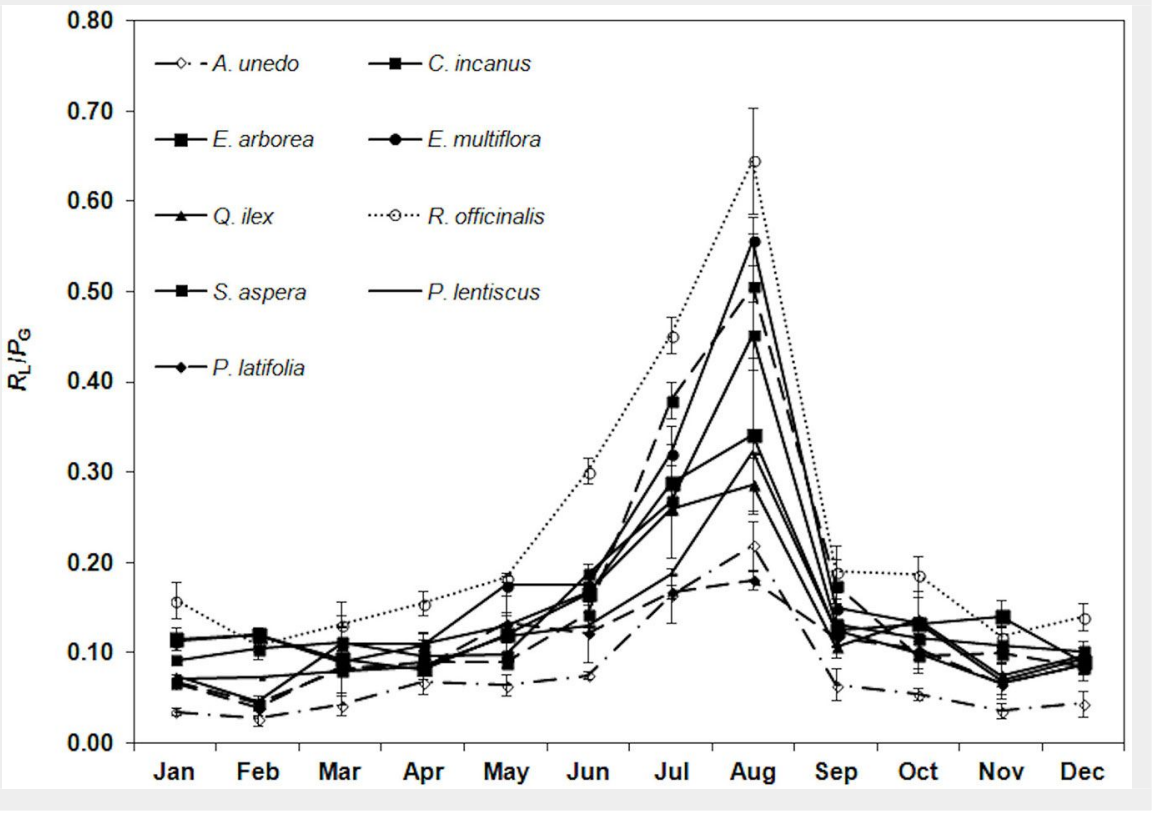

lowed by $A$. unedo, Q. ilex, P. latifolia and $P$. lentiscus $\left(22.6 \pm 7.7 \mu \mathrm{mol} \mathrm{m}^{-2} \mathrm{~s}^{-1}\right.$, mean value), S. aspera, R. officinalis, E. multiflora and $E$. arborea $\left(17.3 \pm 2.0 \mu \mathrm{mol} \mathrm{m} \mathrm{m}^{-2}\right.$, mean value). A $61 \% P_{\mathrm{G}}$ decrease (mean value) than the spring maximum was monitored in August (i.e., during drought), with $C$. incanus and $\mathrm{S}$. aspera having the highest $P_{\mathrm{G}}$ decrease (79\%, mean value) and P. latifolia the lowest (46\%). After the first rainfall, at the beginning of September, $P_{\mathrm{C}}$ increased, on average, by $92 \%$, S. aspera having the highest increase $(>100 \%)$.

$P_{\mathrm{Cy}}$ for the considered species are shown in Fig. 3. In particular, C. incanus showed the highest $P_{\mathrm{Cy}}\left(412 \pm 20 \mathrm{~mol} \mathrm{~m}^{-2}\right)$, followed by Q. ilex, A. unedo, P. latifolia and P. lentiscus (314 $\pm 37 \mathrm{~mol} \mathrm{~m}^{-2}$, mean value), $\mathrm{S}$. aspera, E. arborea, E. multiflora and R. officinalis (208 $\pm 13 \mathrm{~mol} \mathrm{~m}^{-2}$, mean value). The ratio $R_{\mathrm{Ly}} / P_{\text {cy }}$ was the highest in $\mathrm{R}$. officinalis (28\%), followed by E. multiflora and E.arborea (16\%), C. incanus (13\%), S .aspera (12\%),
Q. ilex, P. latifolia and P. lentiscus (11\%, mean value) and $A$. unedo (5\%).

Among all the species, the lowest $R_{\mathrm{L}} / P_{\mathrm{C}}$ ratio (0.07 \pm 0.03 , mean value) was monitored in winter and the highest in August (0.40 \pm 0.15 , mean value). R. officinalis had the highest ratio $(0.65 \pm 0.06)$ and $A$. unedo the lowest ( $0.22 \pm 0.03$ - Fig. 4).

Trend of apparent carboxylation efficiency is reported in Fig. 5. During the study period, the highest $C_{\mathrm{E}}$ was monitored, in all the considered species, in April-May (0.080 $\pm 0.025 \mathrm{~mol} \mathrm{~m}^{-2} \mathrm{~s}^{-1}$, mean value) and the lowest in August ( $0.016 \pm 0.007 \mathrm{~mol} \mathrm{~m}^{-2} \mathrm{~s}^{-1}$, mean value). The mean yearly $C_{\mathrm{E}}$ value was the highest in $C$. incanus $(0.063 \pm 0.034 \mathrm{~mol}$ $\left.\mathrm{m}^{-2} \mathrm{~s}^{-1}\right)$ and the lowest in E. multiflora (0.026 $\left.\pm 0.014 \mathrm{~mol} \mathrm{~m}^{-2} \mathrm{~s}^{-1}\right)$.

Trends of stomatal conductance and transpiration rates are displayed in Fig. 6 (A, B). In particular, $g_{\mathrm{s}}$ showed the same $P_{\mathrm{N}}$ trend with the highest rates in April-May (0.140 \pm $0.06 \mathrm{mmol} \mathrm{m}^{-2} \mathrm{~s}^{-1}$, mean value) and the low- est in August $\left(0.028 \pm 0.011 \mathrm{mmol} \mathrm{m} \mathrm{m}^{-2} \mathrm{~s}^{-1}\right.$, mean value). The lowest $E$ value were monitored in winter (January-February) in all the considered species $(0.639 \pm 0.143$ $\mathrm{mol} \mathrm{m} \mathrm{s}^{-1}$, mean value).

\section{Leaf water status}

The highest $\Psi_{\mathrm{pd}}$ were measured in AprilMay (-0.11 $\pm 0.03 \mathrm{MPa}$, mean value), A. unedo and $E$. multiflora having the highest $\Psi_{\mathrm{pd}}(-0.07 \pm 0.02 \mathrm{MPa}$, mean value) and $R$. officinalis the lowest $(-0.15 \pm 0.01 \mathrm{MPa}) . \Psi_{\mathrm{pd}}$ decreased in August $(-0.89 \pm 0.31$, mean value) $P$. lentiscus having the highest value $(-0.40 \pm 0.09 \mathrm{MPa})$ and $R$. officinalis the lowest $(-1.50 \pm 0.05 \mathrm{MPa})$.

$R W C_{\mathrm{pd}}$ followed the same trend showed by $\Psi_{\mathrm{pd}}$ during the study period, with the highest values in April-May (93.2 $\pm 1.1 \%$ mean values) and a significant decrease in August. Q. ilex, P. latifolia, P. lentiscus and A. unedo had the highest values $(92.0 \pm 1.1$ $\%$ ) and R. officinalis the lowest (78 $\pm 4 \%$ ).
Fig. 5 - Trend of the apparent carboxylation efficiency $\left(C_{\mathrm{E}}, \mathrm{mol} \mathrm{CO}_{2} \mathrm{~mol}^{-1} \mathrm{CO}_{2}\right)$ during the study period. Each point is the mean value of four sampling days per months $(n=24)$. Error bars represent the standard deviation.

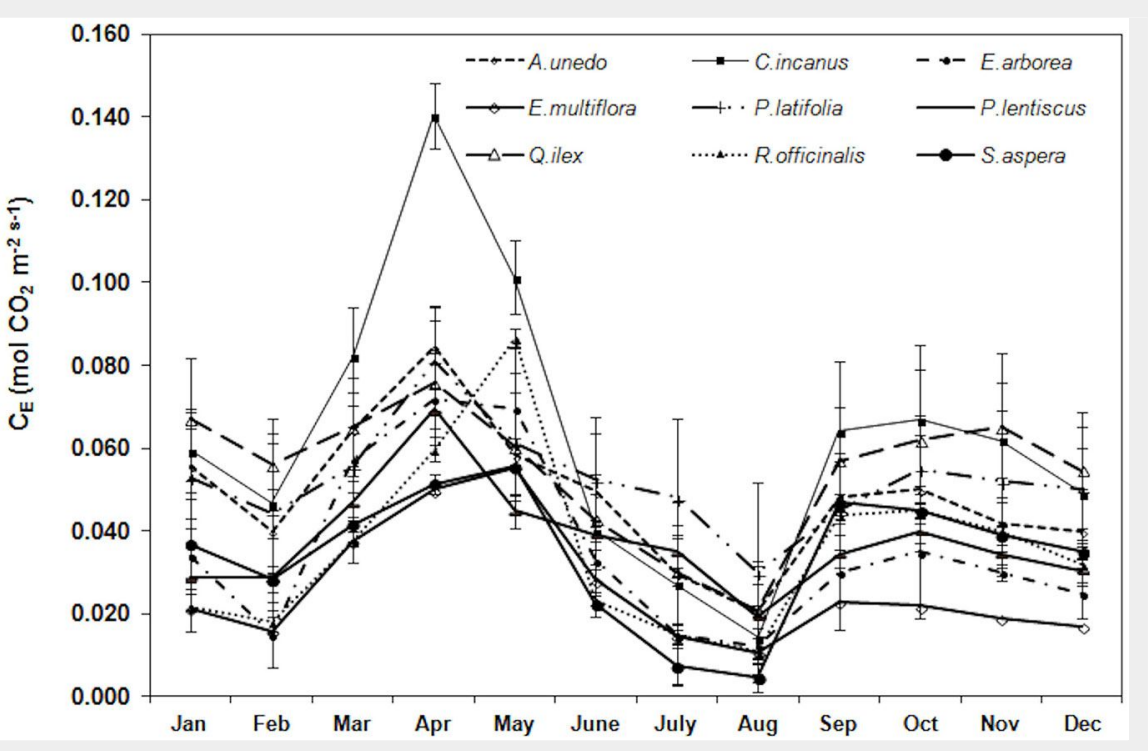




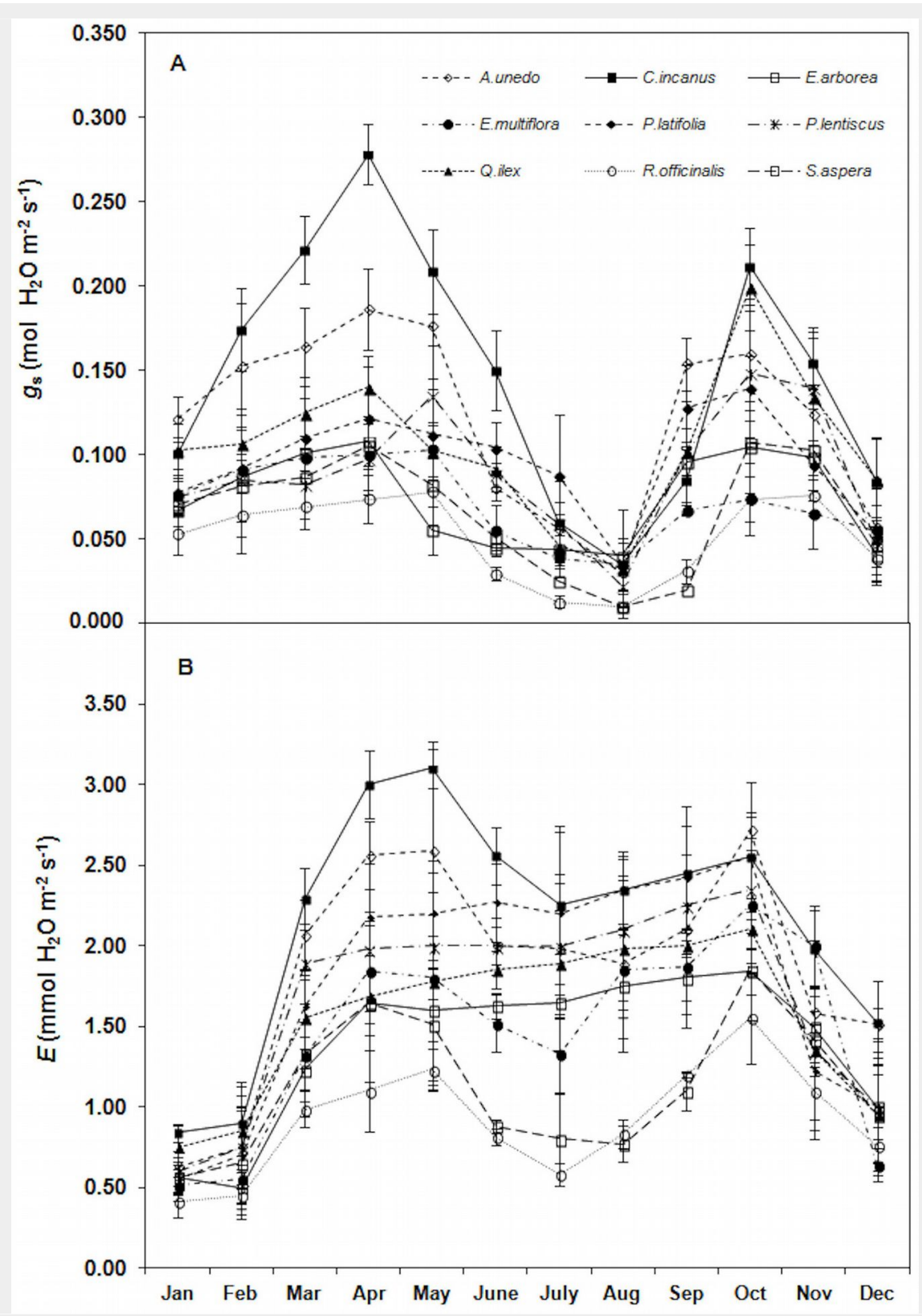

Fig. 6 - Trend of (A) stomatal conductance $\left(g_{\mathrm{s}}, \mathrm{mol} \mathrm{H}_{2} \mathrm{O} \mathrm{m} \mathrm{m}^{-2} \mathrm{~s}^{-1}\right)$ and (B) transpiration rates $\left(E, \mathrm{mmol} \mathrm{H}_{2} \mathrm{O} \mathrm{m}^{-2} \mathrm{~s}^{-1}\right)$ during the study. Each point is the mean value of four sampling days per months $(n=24)$. Error bars represent the standard deviation.

Tab. 4 - Weights of each structural trait in the component 1 and 2 extracted by the Partial Least Squares Regression (PLSR), and variable influence on projection (VIP) values for traits in the component 1. PLSR was carried out with structural traits as predictor variables and physiological traits as response variables. ( $L M A)$ : leaf mass per unit leaf area; $(L T D)$ : leaf tissue density; $(P C I)$ : potential conductance index; $\left(f_{\text {ias }}\right)$ : fraction of mesophyll volume occupied by the intercellular air spaces; $(L T)$ : total leaf lamina thickness; $(C E T)$ : thickness of both upper and lower cuticle and epidermis.

\begin{tabular}{lccl}
\hline Structural trait & Component 1 & Component 2 & VIP \\
\hline$L M A$ & -0.227 & -0.169 & 0.230 \\
$L T D$ & -0.094 & -0.617 & 0.369 \\
$P C I$ & 0.583 & 0.370 & 0.520 \\
$f_{\text {ias }}$ & 0.676 & -0.340 & 0.548 \\
$L T$ & -0.356 & 0.237 & 0.364 \\
$C E T$ & -0.125 & 0.470 & 0.326 \\
Eingenvalues & 1.44 & 1.23 & - \\
\% of explained variance & 24.1 & 20.5 & - \\
\hline
\end{tabular}

\section{Partial least squares regression}

PLSR extracted two significant components which explained $24.1 \%$ (component 1) and $20.5 \%$ (component 2 ) of the original variance in the physiological variables, respectively (Tab. 4). In particular, component 1 was mainly associated to $f_{\text {ias }}$ and $P C I$, while component 2 was mainly associated to LTD and CET. f fias and $P C I$ had the highest VIP (0.548 and 0.520 , respectively), followed by LTD (0.370), LT (0.364), CET (0.326) and LMA (0.260).

Moreover, since a high VIP was found for $P C I$, a simple linear regression analysis was carried out to analyze the relationship between $P C I$ and its components (i.e., $L_{\mathrm{A}}$ and $S D$ ). The results showed that $P C I$ was significantly correlated with $S D(P C I=$ $\left.0.0688 S D-2.3879 ; R^{2}=0.68 ; P \leq 0.05\right)$ while any significant relationship was found between $P C I$ and $L_{\mathrm{A}}(P C I=0.9423$ $\left.L_{\mathrm{A}}-8.5206 ; R^{2}=0.33 ; P>0.05\right)$

\section{Discussion}

Drought resistance in Mediterranean plant species is realized by different traits or combination of traits (Gratani \& Varone 2004). Our results highlight that leaf structural traits can be considered driving factors for physiological traits. This is confirmed by PLS which showed that structural and physiological traits co-vary. Structural trait variations explained $44.61 \%$ of the total variance in $P_{\mathrm{N}}, R_{\mathrm{L}}, R_{\mathrm{L}} / P_{\mathrm{G}}, \Psi$ and $R W C$. The most important structural variables in the physiological trait projection are $f_{\text {ias }}$ and $P C I$, from which the internal $\mathrm{CO}_{2}$ diffusion pattern mainly depends (Puglielli et al. 2015). Photosynthesis and respiration are the most fundamental physiological processes which affect the carbon cycle on a scale ranging from the leaf to the globe (Cavaleri et al. 2008). Moreover, it is recognized that leaf respiration changes are related to physiological factors (Atkin et al. 1997) as well as environmental factors, in particular temperature and water availability (Crous et al. 2011). To date, the $R_{\mathrm{L}}$ behavior during drought is still unclear, since $R_{\mathrm{L}}$ has been found to either increase or decrease depending on the severity of drought stress and the species (Loka et al. 2011).

Overall, our results show a similar $R_{\mathrm{L}}$ response across the considered species, with the lowest rates in winter $(0.95 \pm 0.44$ $\mu \mathrm{mol} \mathrm{m} \mathrm{m}^{-1}$, mean value) and the highest in the dry period $\left(3.05 \pm 0.96 \mu \mathrm{mol} \mathrm{m} \mathrm{m}^{-2} \mathrm{~s}^{-1}\right.$, mean value). This finding supports the hypothesis that $R_{\mathrm{L}}$ increases under drought, which may reflect an enhanced leaf senescence, solute accumulation and energy dissipation by the mitochondria to prevent oxidative damage by excess reductants from light reactions (Atkin \& Macherel 2009). The metabolic damages under drought requires a surplus of respiratory products (i.e., ATP and reducing equivalents - Varone \& Gratani 2015). Thus, $R_{\mathrm{L}}$ increases to meet the demand for higher ATP levels (Atkin \& Macherel 2009). Never- 
theless, a different $R_{\mathrm{L}}$ impact on gross photosynthesis (i.e., $R_{L} / P_{G}$ ) under drought was observed among the considered species. In particular, C. incanus, E. multiflora, R. officinalis and $\mathrm{S}$. aspera show the highest $R_{\llcorner} / P_{\mathrm{G}}$ ( $0.54 \pm 0.08$, mean value) due to a higher

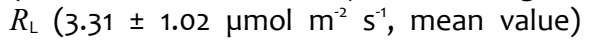
associated to the highest $P_{\mathrm{N}}$ decrease under drought (by $84 \%$, mean value). Differences among the species in $R_{\llcorner} / P_{\mathrm{C}}$ are also related to a different $P_{\mathrm{N}}$ sensitivity to drought, which has a higher inhibitory effect on photosynthesis than on respiration (Flexas et al. 2005). The higher $P_{\mathrm{N}}$ sensitivity to drought is also confirmed by the thermal windows analysis which highlights that $P_{\mathrm{N}}$ drops below half of its maximum when leaf temperature is above $33.4{ }^{\circ} \mathrm{C}$ (mean value of the species - Gratani \& Varone 2004, Catoni 2013). Moreover, $\Psi_{\mathrm{pd}}$ which can be considered a powerful indicator of drought stress (Jones 2007) varies from $-1.30 \pm 0.27 \mathrm{MPa}$ in August to -0.11 0.04 MPa in May (mean of the considered species) associated to a $10 \% R W C_{\mathrm{pd}}$ decrease in August. R. officinalis, C. incanus, and E. multiflora show a lower capacity to adjust photosynthesis in drought also due to their shallow root system (Amato \& Sarnataro 2001), which entails only the access to the superficial soil profile subjected to large changes in water content (Aubert 1978). The response of $R$. officinalis to drought may also be explained by $87 \% g_{s}$ decrease and the lowest PCI $(5.5 \pm 1.4)$ which depends on both stomatal density $(S D=$ $168 \pm 23$ stomata $\left.\mathrm{mm}^{-2}\right)$ and size $\left(S P S_{\text {LAWB }}=\right.$ $\left.219 \pm 47 \mu \mathrm{m}^{2}\right)$. This indicates a low capacity of $R$. officinalis to regulate stomatal conductance (Holland \& Richardson 2009). Moreover, the higher $C_{\mathrm{E}}$ decrease (by $87 \%$ ), indicating a lower Rubisco activity, suggests that in addition to a stomatal limitation, there are a non-stomatal limitation of photosynthesis according to Llorens et al. (2003). On the contrary, Q. ilex, P. latifolia, $P$. lentiscus, $A$. unedo and $E$. arborea are characterized by a lower $R_{\mathrm{L}} / P_{\mathrm{G}}(0.22 \pm 0.05$, mean value) under drought, resulting from a lower $R_{\mathrm{L}}\left(2.55 \pm 0.52 \mu \mathrm{mol} \mathrm{m} \mathrm{m}^{-2} \mathrm{~s}^{-1}\right.$, mean value) and a lower $P_{\mathrm{N}}$ decrease (62\% of the maximum, mean value). The sclerophyllous species and $E$. arborea have a sufficiently higher $\Psi_{\mathrm{pd}}(-0.64 \pm 0.21 \mathrm{MPa}$, mean value) and $R W C_{\mathrm{pd}}$ ( $92 \pm 2 \%$, mean value), reflecting their deep root system which accesses water from those parts of the soil profile subjected to narrow changes in water content (Gratani \& Varone 2004). Moreover, the higher LMA and LTD of these species $\left(17.4 \pm 3.5 \mathrm{mg} \mathrm{cm}^{-2}\right.$ and $523 \pm 73 \mathrm{mg} \mathrm{cm}^{-3}$, mean value, respectively) result in a higher leaf compactness which improves drought resistance. This behavior was also attested by the thermal windows analysis showing that $P_{\mathrm{N}}$ drops below half of its maximum when leaf temperature is above $37.0{ }^{\circ} \mathrm{C}$ (mean value of the species - Gratani \& Varone 2004). A. unedo displays several mechanisms of drought stress resistance (Munné-Bosch \& Peñuelas 2004). It is func- tionally adapted to cope with the summer drought by its stomatal regulation to which contributes a higher PCI $(18.2 \pm 2.8)$ and the steeper leaf inclination angle (Gratani \& Ghia 2002), a mechanism which prevents the potential photo-inhibition of waterstressed leaves during drought (Werner et al. 1999).

With regards to $P_{\mathrm{cy}}$ (i.e., the daily photosynthetic and respiratory activity over the year), $C$. incanus had the highest $P_{\mathrm{Cy}}$ and $R$. officinalis and $E$. multiflora the lowest. In particular, C. incanus maintains a relatively high $R_{\mathrm{L}}$ in spring necessary to produce summer leaves (Catoni et al. 2012, Catoni \& Gratani 2014). The higher $P_{\mathrm{N}}$ in C. incanus is reflected by a higher $f_{\text {ias }}(38 \%)$ and a lower LMA (15.1 $\left.\pm 0.7 \mathrm{mg} \mathrm{cm}^{-2}\right)$, which result from a shorter diffusion path from stomata to chloroplasts (Gratani \& Varone 2004). Moreover, this is consistent with the high $C_{\mathrm{E}}\left(0.063 \pm 0.034 \mathrm{~mol} \mathrm{~m}^{-2} \mathrm{~s}^{-1}\right.$, mean value of the study period) compared to the others species, according to the results of Arena et al. (2013), considering that the apparent carboxylation efficiency is usually correlates with Rubisco activity (Von Caemmerer 2000). On the contrary, the lowest $P_{\text {cy }}$ in $R$. officialis and in E. multiflora mainly reflects the low $P_{\mathrm{N}}$ during the year, as a consequence of the low $C_{\mathrm{E}}$ value $(0.031 \pm 0.007$ mol m $\mathrm{m}^{-2} \mathrm{~s}^{-1}$, mean value) and the lower $f_{\text {ias }}$ (26 $\pm 1 \%$, mean value), associated to a higher LMA and LTD $\left(23.6 \pm 3.9 \mathrm{mg} \mathrm{cm}^{-2}\right.$ and $670 \pm 127 \mathrm{mg} \mathrm{cm}^{-3}$ mean value, respectively).

\section{Conclusions}

The results of this study revealed similar $R_{\mathrm{L}}$ trends across the considered species over the year. Nevertheless, large $R_{\mathrm{L}} / P_{\mathrm{G}}$ variations among the species depend on the different sensitivity of both $R_{\mathrm{L}}$ and $P_{\mathrm{N}}$ to drought. Considering the increase of drought stress which is expected to occur in the Mediterranean basin and that the photosynthesis of Mediterranean evergreen species is frequently limited by suboptimal conditions (i.e., water deficit, high light intensity and high temperature), improving the knowledge of leaf respiration variations and its effect on gross photosynthesis over time will result in a more accurate estimation of carbon balance.

\section{References}

Amato M, Sarnataro M (2001). Root analysis of maquis at Castel Volturno, Italy. In: "ModMED: Modelling Mediterranean Ecosystem Dynamics" (Mazzoleni S, Colin CJ eds). Final Report ModMED III Project, EU-DGXII Environment (IV) Framework, ENV4-ct97-0680, Bussels, Belgium, pp. 110-120.

Arena C, De Micco V, De Maio A, Mistretta C, Aronne G, Vitale L (2013). Winter and summer leaves of Cistus incanus: differences in leaf morphofunctional traits, photosynthetic energy partitioning, and poly(ADP-ribose) polymerase (PARP) activity. Botany 91: 1-9. - doi: 10.1139/cjb-2013-0121

Atkin OK, Macherel D (2009). The crucial role of plant mitochondria in orchestrating drought tolerance. Annals of Botany 103: 581-597. - doi: 10.1093/aob/mcnog4

Atkin OK, Westbeek MHM, Cambridge ML, Lambers H, Pons TL (1997). Leaf respiration in light and darkness (a comparison of slow-and fastgrowing Poa species). Plant Physiology 113: 961965. [online] URL: http://www.plantphysiol.org /content/113/3/961.short

Aubert G (1978). Relations entre le sol et cinq espécies d'ericacées dans le Sud-est de la France [Relationship between soil and five Ericaceae species in the South-Est of France]. Oecologia Plantarum 13: 253-269. [in French]

Bacelar EA, Santos DL, Moutinho-Pereira JM, Lopes JI, Gonçalves BC, Ferreira TC, Correia CM (2007). Physiological behaviour, oxidative damage and antioxidative protection of olive trees grown under different irrigation regimes. Plant and Soil 292: 1-12. - doi: 10.1007/s11104-006-908 8-1

Balasooriya BLWK, Samson R, Mbikwa F, Vitharana UWA, Boeckx P, Van Meirvenne M (2009). Biomonitoring of urban habitat quality by anatomical and chemical leaf characteristics. Environmental and Experimental Botany 65: 386-394. - doi: 10.1016/j.envexpbot.2008.11.009 Brunetti M, Maugeri M, Nanni T, Navarra A (2002). Droughts and extreme events in regional daily Italian precipitation series. International Journal of Climatology 22: 543-558. - doi: 10.1002/joc.751

Castro-Díez P, Villar-Salvador P, Pérez-Rontomé $C$, Maestro-Martínez M, Montserrat-Martí G (1998). Leaf morphology, leaf chemical composition and stem xylem characteristics in two Pistacia (Anarcardiaceae) species along climatic gradient. Flora 193: 195-202.

Catoni R, Gratani L, Varone L (2012). Physiological, morphological and anatomical trait variations between winter and summer leaf of Cistus species. Flora 207: 442-449. - doi: 10.1016/j. flora.2012.02.007

Catoni R (2013). Carbon balance of mediterranean evergreen species. Ph.D. thesis, Ecological Science, "Sapienza" University of Rome, Rome, Italy, pp. 51.

Catoni R, Gratani L (2014). Variations in leaf respiration and photosynthesis ratio in response to air temperature and water availability among Mediterranean evergreen species. Journal of Arid Environment 102: 82-88. - doi: 10.1016/j. jaridenv.2013.11.013

Cavaleri MA, Oberbauer SF, Ryan MG (2008). Foliar and ecosystem respiration in an oldgrowth tropical rain forest. Plant Cell and Environment 31: 473-483. - doi: 10.1111/j.1365-3040. 2008.01775.x

Chastain DR, Snider JL, Collins GD, Perry CD, Whitaker J, Byrd SA (2014). Water deficit in field-grown Gossypium hirsutum primarily limits net photosynthesis by decreasing stomatal conductance, increasing photorespiration, and increasing the ratio of dark respiration to gross photosynthesis. Journal of Plant Physiology 171: 1576-1585. - doi: 10.1016/j.jplph.2014.07.014 Crous KY, Zaragoza-Castells J, Löw M, Ellsworth DS, Tissue DT, Tjoelker MG, Barton CVM, Gimeno TE, Atkin OK (2011). Seasonal acclimation of leaf respiration in Eucalyptus saligna trees: impacts of elevated atmospheric $\mathrm{CO}_{2}$ and sum- 
mer drought. Global Change Biology 17: 15601576. - doi: 10.1111/j.1365-2486.2010.02325.x

Flexas J, Galmés J, Ribas-Carbo M, Medrano H (2005). The effects of water stress on plant respiration. In: "Plant respiration: from cell to ecosystem” (Lambers H, Ribas-Carbo M eds). Kluwer Academic Publishers, Springer, Dordrecht, Netherlands, vol. 18, pp. 85-94. - doi: 10.1007/1-4020-3589-6_6

Galmés J, Ribas-Carbó $M$, Medrano H, Flexas J (2007). Response of leaf respiration to water stress in Mediterranean species with different growth forms. Journal of Arid Environment 68: 206-222. - doi: 10.1016/j.jaridenv.2006.05.005

Giannakopoulos C, Le Sager P, Bindi M, Moriondo M, Kostopoulou E, Goodess CM (2009). Climatic changes and associated impacts in the Mediterranean resulting from a $2{ }^{\circ} \mathrm{C}$ global warming. Global and Planetary Change 68: 209224. - doi: 10.1016/j.gloplacha.2009.06.001

Goubanova K, Li L (2007). Extremes in temperature and precipitation around the Mediterranean basin in an ensemble of future climate scenario simulations. Global and Planetary Change 57: 27-42. - doi: 10.1016/j.gloplacha.200 6.11 .012

Gratani L, Crescente MF (1997). Phenology and leaf adaptive strategies of Mediterranean maquis plants. Ecologia Mediterranea 23 (3/4): 11-19.

Gratani L, Bombelli A (2000). Correlation between leaf age and others leaf traits in three Mediterranean maquis shrub species: Quercus ilex, Phillyrea latifolia and Cistus incanus. Environmental and Experimental Botany 43: 141153. - doi: 10.1016/So098-8472(99)00052-0

Gratani L, Ghia E (2002). Adaptive strategy at the leaf level of Arbutus unedo L. to cope with Mediterranean climate. Flora 197: 275-284. - doi: 10.1078/0367-2530-00041

Gratani L, Varone L (2004). Adaptive photosynthetic strategies of the Mediterranean maquis species according to their origin. Photosynthetica 42: 551-558. - doi: 10.1007/S11099-005-0012-3 Gratani L, Varone L, Ricotta C, Catoni R (2013). Mediterranean shrublands carbon sequestration: environmental and economic benefits. Mitigation Adaptations Strategies of Global Change 18: 1167-1182. - doi: 10.1007/s11027-012-9 415-1

Hamann A, Wang T (2006). Potential effects of climate change on ecosystem and tree species distribution in British Columbia. Ecology 87: 2773-2786. - doi: 10.1890/0012-9658(2006)87[27 73:PEOCCO]2.0.CO;2

Holland N, Richardson AD (2009). Stomatal length correlates with elevation of growth in four temperate species. Journal of Sustainable Forestry 28: 63-73. - doi: 10.1080/1054981080 2626142

IPCC (2014). Summary for policymakers. In: “Climate Change 2014: Impacts, Adaptation, and Vulnerabil-ity. Part A: Global and Sectoral Aspects. Contribution of Working Group II to the Fifth Assessment Report of the Intergov- ernmental Panel on Climate Change" (Field CB, Barros VR, Dokken DJ, Mach KJ, Mastrandrea MD, Bilir TE, Chatterjee M, Ebi KL, Estrada YO, Genova RC, Girma B, Kissel ES, Levy AN, MacCracken S, Mastrandrea PR, White LL eds). Cambridge University Press, Cambridge, United Kingdom and New York, NY, USA, pp. 1-32.

Jones HG (2007). Monitoring plant and soil water status: established and novel methods revisited and their relevance to studies of drought tolerance. Journal of Experimental Botany 58: 119-130. - doi: 10.1093/jxb/erl118

Karabourniotis G (1998). Light-guiding function of foliar sclereids in the evergreen sclerophyll Phillyrea latifolia: a quantitative approach. Journal of Experimental Botany 49: 739-746. - doi: 10.1093/jxb/49.321.739

Larcher W (2003). Physiological plant ecology. Springer-Verlag, Berlin, Heidelberg, Germany, pp. 514. [online] URL: http://books.google. com/books?id=BgtzD4frrg8C

Llorens L, Peñuelas J, Estiarte M (2003). Ecophysiological responses of two Mediterranean shrubs, Erica multiflora and Globularia alypum, to experimentally drier and warmer conditions. Physiologia Plantarum 119: 231-243. - doi: 10.1034/j.1399-3054.2003.00174.x

Loka D, Oosterhuis D, Ritchie G (2011). Waterdeficit stress in cotton. In: "Stress physiology in cotton" (Oosterhuis DM eds). The Cotton Foundation, Cordova, TN, USA, pp. 37-72.

Moretti V, Di Bartolomei R, Sorgi T, Aromolo R, Salvati $L$ (2015). Soil water deficit and climate conditions during the dry season along the coastal-inland gradient in Castelporziano forest, central Italy. Rendiconti Lincei Scienze Fisiche e Naturali 26: 283-288. - doi: 10.1007/s1221 0-014-0336-7

Munné-Bosch S, Peñuelas J (2004). Droughtinduced oxidative stress in strawberry tree (Arbutus unedo L.) growing in Mediterranean field conditions. Plant Science 166: 1105-1110. doi: 10.1016/j.plantsci.2003.12.034

Pereira JS, Mateus JA, Aires LM, Pita G, Pio C, David JS, Andrade V, Banza J, David TS, Paço TA, Rodrigues A (2007). Net ecosystem carbon exchange in three contrasting Mediterranean ecosystem'the effect of drought. Biogeosciences 4: 791-802. - doi: 10.5194/bg-4-791-2007

Puglielli G, Crescente MF, Frattaroli AR, Gratani L (2015). Leaf Mass Per Area (LMA) as a possible predictor of adaptive strategies in two species of Sesleria (Poaceae): analysis of morphological, anatomical and physiological leaf traits. Annales Botanici Fennici 52 (1-2): 135-143. - doi: 10.5735/085.052.0201

Reich PB, Uhl C, Walters MB, Ellsworth DS (1991). Leaf lifespan as a determinant of leaf structure and function among 23 tree species in Amazonian forest communities. Oecologia 86: 16-24. doi: $10.1007 / B F 00317383$

Reich PB, Ellsworth DS, Walters MB, Vose JM, Gresham C, Volin JC, Bowman WD (1999). Generality of leaf trait relationships: A test across six biomes. Ecology 80: 1955-1969. - doi:
10.1890/0012-9658(1999)080[1955:GOLTRA]2. $0 . \mathrm{CO} ; 2$

Rotondi A, Rossi F, Asunis C, Cesaraccio C (2003). Leaf xeromorphic adaptations of some plants of a coastal Mediterranean macchia ecosystem. Journal of Mediterranean Ecology 4 (3/4): 2535. [online] URL: http://www.jmecology.co m/wp-content/uploads/2014/03/04rotondi.pdf Sack L, Grubb PJ, Marañón T (2003). The functional morphology of juvenile plants tolerant of strong summer drought in shaded forest under stories in southern Spain. Plant Ecology 168: 139-163. - doi: 10.1023/A:1024423820136

Schulze ED, Fuchs MI, Fuchs M (1977). Spacial distribution of photosynthetic capacity and performance in a mountain spruce forest on northern Germany. I. Biomass distribution and daily $\mathrm{CO}_{2}$ uptake in different crown layers. Oecologia 29: 43-61. - doi: 10.1007/BFo0345361 Syvertsen JP, Lloyd J, McConchie C, Kriedemann PE, Farqhar GD (1995). On the relationship between leaf anatomy and $\mathrm{CO}_{2}$ diffusion through the mesophyll of hypostomatous leaves. Plant Cell and Environment 18: 149-157. - doi: 10.1111/j. 1365-3040.1995.tboo348.x

Sternberg M, Shoshany M (2001). Influence of slope aspect on Mediterranean woody formations: comparison of a semiarid and an arid site in Israel. Ecological Research 16: 335-345. - doi: 10.1046/j.1440-1703.2001.00393.x

Stojnić S, Orlović S, Trudić B, Zivković U, Von Wuehlisch G, Miljković D (2015). Phenotypic plasticity of European beech (Fagus sylvatica L.) stomatal features under water deficit assessed in provenance trial. Dendrobiology 73: 163-173. doi: 10.12657/denbio.073.017

Sun J, Wu J, Guan D, Yao F, Yuan F, Wang A, Jin C (2014). Estimating daytime ecosystem respiration to improve estimates of gross primary production of a temperate forest. PLoS ONE 9 (11): e113512. - doi: 10.1371/journal.pone.0113512

Van lersel MW (2003). Carbon use efficiency depends on growth respiration, maintenance respiration, and relative growth rate. A case study with lettuce. Plant Cell and Environment 26: 1441-1449. - doi: 10.1046/j.0016-8025.2003.0106 7.x

Varone L, Gratani L (2015). Leaf respiration responsiveness to induced water stress in Mediterranean species. Environmental and Experimental Botany 109: 141-150. - doi: 10.1016/j.env expbot.2014.07.018

Von Caemmerer S (2000). Biochemical models of leaf photosynthesis. CSIRO Publishing, Collingwood, Victoria, Australia, pp. 165. [online] URL: http://books.google.com/books?id=Nxox4F3U7 jgC

Werner C, Correia O, Beyschlag W (1999). Two different strategies of Mediterranean macchia plants to avoid photoinhibitory damage by excessive radiation levels during summer drought. Acta Oecologica 20: 15-23. - doi: 10.1016/S1146-609X(99)80011-3 